DOI: 10.14526/2070-4798-2019-14-4-103-110

\title{
Students' communicative competency formation in terms of interaction with pupils of educational establishment
}

\author{
Marina M. Shubovich*, Nadezhda N. Petrishcheva \\ Ulyanov State Pedagogical University \\ Ulyanovsk, Russia \\ ORCID: oooo-ooo2-8325-8626, shubmm@mail.ru \\ ORCID: oooo-Ooo1-8435-5607,nadin.1984_2011@mail.ru
}

\begin{abstract}
The authors, substantiating the urgency of the research, underline that nowadays the broadening information sphere, conditions the development of existing teacher's competencies, constant format of knowledge renewal.Communicative competency is one of the most important parts of professional competency, the aim of which is the ability to achieve productivity in communication. Materials. As the initial materials we specified the essence of the basic notions: "Communicative competency", "Students-future physical culture teachers", "Conditions of interaction", "Communicative competency formation" and analyzed the main definitions. Research methods. The research was held on the basis of Ulyanovsk State Pedagogical University named after I.N. Ulyanov among students from physical culture and sport faculty. The aim of the research was in the program realization, which includes two blocks of events, directed toward the level of communicative competency increase among students- future physical culture teachers during the process of interaction with pupils at an educational environment: block 1 includes events, directed toward the level of communicative competency increase among students-future physical culture teachers during the process of interaction with pupils using active forms of teaching; block 2 includes events, directed towards inner potential revelation, toward individual personality and style of behavior stimulation among students-future physical culture teachers. Results. The held research and control diagnostics showed that program events provided communicative competency formation among students-future physical culture teachers in terms of interaction with pupils of educational establishment, created conditions for communication, developed communicative abilities, formed the skills of relations regulation between the participants of the educational process and adaptation in collective. Conclusion. Studying the role of communicative competency of students-future PC teachers in the future can become the base for further many-sided research of the personality's communicative competency creation and realization effective technologies problem.
\end{abstract}

Keywords: "communicative competency", students-future physical cultureteachers", "conditions of interaction", communicative competency formation.

For citation: Marina M. Shubovich*, Nadezhda N. Petrishcheva. Students' communicative competency formation in terms of interaction with pupils of educational establishment. Russian Journal of Physical Education and Sport. 2019; 14(4): 87-93. DOI: 10.14526/2070-4798-2019-14-4-103-110.

\section{INTRODUCTION}

In terms of global digitalization the system of education in Russia undergoes serious changes and the presented style of pedagogical interaction in a modern system of education, integrated into constantly broadening information field, conditions constant development of the existing teacher's competencies, the format of knowledge change and new competencies formation. Today knowledge actively gains the form of context, in terms of which demanded become meta-competencies, as this format is necessary, both for new knowledge gaining and the existing knowledge transfer. In order to develop the competencies of a modern teacher's personality " $4 \mathrm{~K}$ " model is used. It was created by company Partnership for 21st Century Skills in 2014. " $4 \mathrm{~K}$ " is a system of 4 key skills of over-professional competencies: critical thinking, creativity, team work and communication, which help a modern teacher to climb different stages of own professional-personal development and pedagogical mastery development[1].

I. Braun presents $4 \mathrm{~K}$ model in which he underlines that communication today is the situation and results of interaction estimation; this dialogue is the attempt to understand the partner, 
clear messages formation and getting, auxiliary communicative means use [1].

\section{MATERIALS AND METHODS}

As the initial materials we specified the essence of the basic notions: "Communicative competency", "Students-future physical culture teachers", "Conditions of interaction", "Communicative competency formation".

Communicative competency is one of the most important parts of students-future teachers professional competency, the aim of which is the ability formation to achieve productivity in communication in terms of a qualitative optimal level of interaction in educational environment. Teacher's communicative competency development is necessary in oral and written communication, text creation and perception, commercial correspondence, office work, foreign communication and communicative objectives solution.

Different aspects of communicative competency consideration was reflected in the works of B.Z. Vulfov, I.A. Zimnyaya, Yu.M. Zhukov, S.A.Ignatev, N.V. Kuzmina, L.A. Petrovskaya, P.V. Rastyannikov, N.P. Fetiskin, V.D. Shirshov, T.N. Shcherbakova and others.

It should be noted that in scientific literature this definition is quite difficult. N.P. Fetiskin mentions that a teacher, who has communicative competency, can easily communicate, achieve desired results in communication, avoiding negative effects, quickly and effectively contact, listen and hear the opponent, explain own point of view in the format "equal to equal" [11]. In the research works by Yu. M. Zhukov, L.A. Petrovskaya, P.V. Rastyannikov communicative competency is understood as the ability to set and support necessary contacts with other people [3, p. 3].

According to Merlin V.S. communicative competency can be defined in two aspects: as the personality's orientation in different situations of communication, based on lessons and sensitive experience and as the ability to interact effectively with people around, owing to understanding oneself and other people for constant change of psychic states, interpersonal relations and conditions of social environment [8 p.175].
Structural components of communicative competency defining is considered by the example of the model created by I.A. Zimnyaya. This model reveals the following: - motivation-axiological component, presented by professional motivation, which is included into the motivation of study, pedagogical activity itself and its values, readiness of a teacher to realize professional development; reflects the interest in innovative activity, desire to self-development and self-actualization, the need for pedagogical improvement of a teacher; - cognitive component means knowledge of communicative competency essence and role, the ability to solve the problems, which appear during communication and interaction of a teacher and pupils in educational environment; -operational-activity based (behavioral) component forms communicative skills, which are necessary for a teacher in different standard and non-standard situations, the ability of a teacher to realize personality oriented interaction during educational process, the ability to preserve emotional balance, prevent and solve conflicts using effective way, having oratorical skill, correct oral and written speech, the ability to create the tactics, technique and strategy of an active interaction with people, organize their mutual activity in order to achieve the definite socially important aims, the ability to estimate objectively the situation of interaction between objects of educational process, predict and substantiate the result of an effective interaction in educational environment [4, p.11].

All components are connected, interdependent and a high level of a teacher's communicative competency, ideally, provides all mentioned above components development.

Mentioned above components (criteria) can be used in terms of students-future physical culture (PC) teachers. We define motivational, cognitive and activity-based criteria of communicative competency of students-future PC teachers. 
Table 1 - Communicative competency criteria correspondence among students-future PC teachers with diagnostic instruments for their estimation.

\begin{tabular}{|c|c|c|}
\hline № & Criteria & Diagnostic instruments of evaluation \\
\hline 1. & Motivational & $\begin{array}{r}\text { Motivational orientations diagnostics in interpersonal } \\
\text { communications (I. Ladanov, V. Urazaeva) }\end{array}$ \\
\hline 2. & Cognitive & $\begin{array}{c}\text { Dominating perceptive modality diagnostics (S. Efremtsev), } \\
\text { Communicative tolerance diagnostics (V. Boyko) }\end{array}$ \\
\hline 3. & Activity-based & Communicative control diagnostics (M. Shayder) \\
\hline
\end{tabular}

The components of communicative competency and the criteria of their demonstration revelation helps to select diagnostic instruments and estimate the studied phenomenon.

Nowadays physical culture teacher in professional activity has to know the techniques of verbal and non-verbal communication, the ability to create social-pedagogical situations, in which students practice in setting contacts with people around, in applying for help, advice, making correct communication. The effectiveness of educational process depends on the success of interpersonal interaction, the ability to involve into mutual activity.

Physical culture teacher should have sufficient level of communicative competency, be able to realize personality oriented educational and communicative technologies and be ready to control educational process. Communicative competency of physical culture teacher is considered as the ability to realize successful and effective pedagogical interaction with all participants of educational environment and with social environment in order to solve a wide variety of pedagogical objectives.

In adopted in 2009 Strategy of physical culture and sport development for 2020, human resources improvement is presented as one of the directions of state politic in the sphere of physical culture and sport [10]. It is connected with the fact that physical culture and sport is a social sphere, on the effectiveness of which depends physical, spiritual, intellectual health and well-being of a personality and society in general.

It means that the urgency of communicative competency formation among physical culture teachers is conditioned by the following aspects: dynamic character of life and professional activity, which demands the following qualities from physical culture teachers: communication skills, culture of communication, the ability to adapt in collective of educational organization, regulate relations between the participants of educational process; - specificity of the physical culture and sport specialists activity, as they can realize both pedagogical (being physical culture teachers and coaches) and managerial and recreational activity; - the profession refers to "person-person" system, where communication is one of significant categories during interaction.

The research works by G.D. Babushkin, M.Ya. Vilenskiy, S.B. Elkanov, Yu.M. Zhukov, E.P. Ilin, I.F. Isaev, N.V. Kuzmina, A.I. Chuchalina and others considered the questions of communication, pedagogical communication and speech activity in professional training of specialists, in particular the sphere of physical culture and sport.

It is known that a teacher's word provides notions formation concerning these or that phenomena in nature and society. Physical culture teacher's word helps to create a motor image and then motor skills and abilities formation.

Physical culture teacher's specificity of professional speech depends on many factors, but first of all on time deficiency and the character of actions during the lessons [3].

During the process of interaction with pupils physical culture teacher decides, which task, question it is reasonable to ask this or that pupil, how to make him or her believe in own abilities, how to say in order not to offence a pupil and make him or her understand real motives of a teacher.

Interaction is a process, which is defined by E.V. Korotaeva, as "the connection of education subjects (and objects), determined by cognitive situation, conditioned by social-psychological 
processes, which lead to quantitative-qualitative changes" [7, p.67]. The author thinks that the base of pedagogical interaction is the theory of activity. It includes psychological concept of interpersonal interactions and is studied from the point of view of the process and result of psychological-pedagogical activity of the participants of interaction [7, p. 68]. Supporting this idea E.V. Meshcheryakova, who underlines, that pedagogical interaction is the process of mutual activity. It has general pedagogical aim [9].

The demands claimed on modern physical culture teacher are high, but as the practice shows, students-future physical culture teachers are not always ready to cope with these objectives in their practical activity. Competencies analysis, connected with communication and interaction, included into federal state educational standard of higher education - bachelor degree in the following direction if training 44.03.01 Pedagogical education (Federal State Educational Standard) (on the basis of which there is future physical culture teachers training at a higher educational establishment), shows their restricted list (table 2).

Table 2 The categories of universal and general professional competencies, included into FSES 44.03.01, which are included into communication and interaction.

\begin{tabular}{|l|l|l|}
\hline No & $\begin{array}{l}\text { Category of universal (UC) and general- } \\
\text { professional competencies (GPC) }\end{array}$ & Code of competence \\
\hline 1. & Communication & $\begin{array}{l}\text { UC-4 Is able to realize business communication } \\
\text { in oral and written forms using state language of } \\
\text { the Russian Federation and foreign language }\end{array}$ \\
\hline 2. & $\begin{array}{l}\text { Interaction with the participants of } \\
\text { educational relations }\end{array}$ & $\begin{array}{l}\text { GPC-7 Is able to interact with the participants } \\
\text { of educational relations in terms of educational } \\
\text { programs realization. }\end{array}$ \\
\hline
\end{tabular}

The table shows that only one (UC-4) is directed toward communicative competency formation among the future physical culture teachers and one (GPC-7) toward interaction formation with the participants of relations (from general list of 16 competencies, presented in FSES). It is not enough in terms of students-future physical culture teachers professional training at a higher educational establishment.

\section{RESULTS AND DISCUSSION}

The experiment was held on the basis of Ulyanov State Pedagogical University, Ulyanovsk, Russia. The aim of the experiment was the conditions determinations, which provide communicative competency formation among students-future physical culture teachers in terms of interaction with the students of educational organization. 45 students from physical culture and sport department took part in the experiment. They were from the $3^{\text {rd }}$ and the $4^{\text {th }}$ courses. 22 people were included into the control group (CG) and 23 people were included into the experimental group (EG). The experiment had three stages. At the first stage, stating stage of the experiment, we held the diagnostics in the respondents from both groups in order to define the level of communicative competency formation with the help of mentioned above instruments. The respondents were divided into three levels: basic (39\% EG) and (36,6\% CG) - according to motivational component; advanced $(51,2 \%$ EG) and (53,7 CG)- according to cognitive component; and the increased (9,3\% EG) and (7,3\% CG)- activity based component. It proves insufficient level of communicative competency formation (table 3 ).

At the second, teaching stage of the experiment, we created the program, which included two blocks of events. They were directed toward the level of communicative competency level increase among students- future physical culture teachers during interaction with pupils in educational environment: Block 1 Events, directed toward the level of communicative competency increase in students-future PC teachers during interaction with pupils using active forms of teaching, such as modeling, play activity (games-competitions, 
games-discussions,

games-reconstructions);

communicative dialogue, debating activity (seminar, discussions, problem based-project discussions). Block 2 Events, directed toward inner potential revelation of students-future PC teachers, toward individual-personal style stimulation (practical lessons, research based lessons); trainings (for creativity, reflexion, empathy, tolerance development).

Control stage of the experiment included additional diagnostics of communicative competency level formation among students-future PC teachers in both groups. Positive dynamics of communicative competency formation process among studentsfuture PC teachers according to three criteria is proved by the results of the experimental work (table 3). According to activity based criteria we see that the improved level of communicative competency formation in the EG corresponds with $46,5 \%$ of respondents, in the CG- 9,8\%. Basic level indices according to activity based criterion in the EG were 4,7\%, in the CG-39,o. Thus, the indices of basic level according to activity-based criterion among the EG students decreased 10 times, in the CG- less than twice. Diagnostics results analysis shows significant respondents transfer according to all three criteria in the EG in comparison with the CG from the basic level to improved one. It proves effectiveness of communicative competency conditions formation among students-future PC teachers.

Table 3 - Results of communicative competency levels diagnostics among students-future PC teachers

\begin{tabular}{|l|l|c|c|c|c|c|}
\hline & \multicolumn{4}{|l|}{ I stage. Stating } & \multicolumn{2}{l|}{ II stage. Control } \\
\hline Components & Levels & EG, \% & CG, \% & Levels & EG, \% & CG, \% \\
\hline \multirow{5}{*}{ Motivational } & Basic & 39,5 & 36,6 & Basic & 4,7 & 26,8 \\
\cline { 2 - 8 } & Advanced & 46,5 & 48,8 & Advanced & 48,8 & 53,7 \\
\cline { 2 - 7 } & Improved & 14,0 & 14,6 & Improved & 46,5 & 19,5 \\
\hline Cognitive & Basic & 23,3 & 22,0 & Basic & 2,3 & 21,9 \\
\cline { 2 - 8 } & Advanced & 51,2 & 53,7 & Advanced & 37,2 & 51,2 \\
\cline { 2 - 8 } & Improved & 25,6 & 24,4 & Improved & 60,5 & 26,9 \\
\hline Activity based & Basic & 48,8 & 43,9 & Basic & 4,7 & 39 \\
\cline { 2 - 7 } & Advanced & 41,9 & 48,8 & Advanced & 48,8 & 51,2 \\
\cline { 2 - 7 } & Improved & 9,3 & 7,3 & Improved & 46,5 & 9,8 \\
\hline
\end{tabular}

\section{CONCLUSION}

Thus, program events provided communicative competency formation in studentsfuture PC teachers in terms of interaction with pupils from educational organization, conditions for communication creation communicative skills development, formed the skills of relations regulation between the participants of educational process and adaptation in collective.

\section{REFERENCES}

1.Aleksandrov Yu.M., Kolesnik I.S. Strength and variability of a motor skill as the factors of sportsmanship improvement. Pedagogikopsichologicheskie I medico-biologicheskie problemy fizichrskoj kul'tury I sporta. 2013; 4(29): 24-30. URL: http://www/kamgifk.chelny.net/journal (In Russ.).
2.

Brun I. Izmerenie kompetencij XXI veka. Moskva, 16-18 fevralya 2017 [Measuring competencies of the XXI century. Moscow, February, 16-18, 2017]. IV Summer school "Theory and practice of tests creation”. URL: https://ioe. hse.ru/monitoring/4k/monitoring/materials. (In Russ.)

3. Zhukov Yu.M. Kommunikativnyj trening [Communicative training]. Moscow: Gardariki. 2003: 223.

4. Ilin E.P. Psihologiya sporta [Psychology of sport]. Saint-Petersburg: Piter. 2008: 352 .

5. Zhukov Yu.M., Petrovskaya L.A., Rastyannikov A.V. Fiagnostika I razvitie kompetentnosti $v$ obchenii [Diagnostics and development of competency in communication]. Moscow: Moscow University publishing house. 
1990: 104 (In Russ.).

6. Zimnyaya I.A. Key competencies as a new paradigm of education result. Experiment $I$ innovacii v shkole. 2009; 2: 7-14 (In Russ.).

7. Isaev I.F. Teoriya I praktika formirovaniya professional'no-pedagogicheskoj kul'tury prepodavatelya vysshej shkoly [Theory and practice of higher education teacher's professionalpedagogical culture formation]. Moscow. Belgorod. 1993: 142 (In Russ.).

8. Korotaeva E.V. Osnovy pedagogiki vzaimodejstvij: teoriya I praktika: monografiya [The basis of pedagogics of interactions: theory and practice: monograph]. Ekaterinburg: Ural State Pedagogical University publishing house. 2013: 203.

9. Kolesnik I.S., Gatin F.A., Osipov D.A. Communicative skills formation during sports training of boxers. Pedagogiko-psihologicheskie I medico-biologicheskie problemy fizicheskoj kul'turyi sporta $=$ Pedagogico-psychological and medico-biological problems of physical culture and sport. 2016; 1(11): 40-46. DOI:10.14526/01_1111_77 (In Russ., In Engl.)

10. Merlin V.S. Ocherk integral'nogo issledovaniya individual'nosti [Essay of an integral individuality study]. Moscow: Pedagogics. 1986: 253.

11. Meshcheryakova E.V. Theory and practice of a teacher's professional training for pedagogical interaction in modern educational environment (by the material of training Foreign language teacher). Doctor's thesis. Moscow. 2002: 395 .

12. Strategy of physical culture and sport development in the Russian Federation during the period till 2020, decree of the Russian Federation Government on August 7, 2009 № 1101-r. URL: http://www.sportspravka.com/main. mhtml?Part $=35$

13. Fetiskin N.P., Kozlov V.V., Manuylov G.M. Social'no-psihologicheskaya diagnostika razvitiya lichnosti I malyh grupp [Social-psychological diagnostics of personality and small groups development]. Moscow: Psychotherapy. 2009: 544 (In Russ.).

14. Shubovich M.M. Competency based approach as the ideology of modern personalityoriented education. Vestnik Kazanskogo Technologicheskogo Universiteta. 2009; 5: 397403 (In Russ.).

15. Shubovich M.M. Active forms of teaching during professional training of social officials at a higher educational establishment. Vestnik social'noj raboty I social'noj politiki. 2005; 6: 114-119 (In Russ.).

16. Shubovich M.M., Dolina O.I. Communicative culture of a family as the object of professional activity of a social official. $V$ bornike: uchebnyj process, realizaciya ego osnovopolagayuchih funkcij $v$ sovremennyh usloviyah. Mezhvuzovskij sbornik nauchnyh trudov [In collection of works: Educational process, its basic functions realization in modern conditions. Interuniversity collection of scientific works]. I.N. Ulyanov State University, Cheboksary. 2004: 30-33 (In Russ.).

17. American College of Sports Medicine. Physical activity programs and behavior counseling in older adult populations. Medicine and Science in Sports and Exercise. 2004; 36(11): 19972003.

18. Bauman A.E. Physical activity and exercise programs. Physical activity and health. 2007: 319-334. Biddle S.J.H., Atkin A., Cavill N., Foster C. Correlates of physical activity in youth: A review of quantitative systematic reviews. International Review of Sport and Exercise Psychology. 2011; 4(1): 25-49.

19. Bize R., Johnson J.A., Plotnikoff R.C. Physical activity level and health-related quality of life in the general adult population: A systematic review. Preventive Medicine. 2007; 45(6): 401-415.

20. Brehm W., Wagner P., Sygusch R., Hahn U., Janke A. Health Promotion by means of Health Sport. A framework and a controlled intervention study with sedentary adults. Scandinavian Journal of Medicine and Science in Sports. 2005; 15(1): 13-20.

21. Nazarenko L.D., Kolesnik I.S. Physiological bases of improvement system of boxers sports training. Life Science Journal. 2014; 11(11s): 642-645. URL: http://www.lifesciencesite. com. 


\section{Submitted: 30.11.2019}

\section{Author's information:}

Marina M. Shubovich - Doctor of Pedagogics, Professor, Ulyanov State Pedagogical University, Ulyanosk, 43270o, Russia, Ulyanovsk, Lenin's square, House 4/5, e-mail: shubmm@mail.ru

Nadezhda N. Petrishcheva - Assistant, Ulyanov State Pedagogical University, Ulyanosk, 43270o, Russia, Ulyanovsk, Lenin's square, House 4/5, e-mail: nadin.19842011@mail.ru 